\title{
Olhar viajante: Antropologia, criança e aprendizagem
}

\author{
Neusa Maria Mendes de Gusmão*
}

Resumo: $\mathrm{O}$ presente texto procura aproximar a Antropologia do percurso e do itinerário de Mário de Andrade e suas relaçóes com o universo infantil. Nesse intuito, assume, por princípio, que as crianças, de qualquer grupo, sociedade ou cultura, sabem de si, sabem onde estáo, o que faz parte de suas vidas; conhecem seu mundo; e se confrontam com os princípios de pertença e identidade que lhes são atribuídos. Assim, no mais profundo dos cotidianos sociais de diferentes grupos, opera a percepção de mundo, que se constrói como parte de um conhecimento, por vezes naturalizado, e que exige ser desnaturalizado por meio da compreensáo das múltiplas linguagens do social, inscritas nas dimensóes ocultas do cotidiano, num trânsito entre o real instituído e o real instituinte. Ressalta-se que o trânsito e o itinerário em que atuou Mário de Andrade na sua busca pelo imaginário da infância são os mesmos que a Antropologia percorre no debate da infância, da criança, da cultura e da sociedade.

Palavras-chave: Antropologia; criança; aprendizagem; cultura; Mário de Andrade.

\section{A travelling look: anthropology, children and learning}

Abstract: The discussion of Anthropology as a science in dialogue with other fields of knowledge, among them education, puts the science we practice in the center of discussion and its effects or consequences when it is used to go from one field to another. The notion of culture becomes emblematic of this process, especially in American Cultural Studies which echoes in education more than it does in Latin America. Over there, the anthropological tradition is still recognized by its political and explanatory importance. This debate highlights the need for the anthropology of education to be modern and critical, a field under construction. This "new anthropology" should be present in the training of educators and social scientists, in order to confer autonomy and social responsibility to those intellectual working professionals, who educate and search various social realities to build knowledge.

Key words: anthropology; children; learning; culture; Mário de Andrade.

E há sempre que distinguir entre ensino e aprendizagem: o primeiro é feito pela escola e pelos adultos e a segunda

só pela criança

(Iturra, 1997)

Em minhas pesquisas, tenho trabalhado com os "quotidianos marginais desvendados pelas crianças", em narrativas, em textos culturais expressos por diferentes

* Antropóloga e professora titular do Departamento de Ciências Sociais na Educação (Decise) da Faculdade de Educação da Unicamp, Campinas, SP, Brasil.neusagusmao@uol.com.br

Pro-Posiçóes, Campinas, v. 23, n. 2 (68), p. 161-178, maio/ago. 2012 
formas e meios, por diferentes linguagens: da fala ao corpo, da ação à representação, da escrita à oralidade, dos gestos aos grafismos, à dança e demais formas possíveis de expressão, arte e comunicação, que constituem um complexo jogo de imagens. Trata-se das muitas linguagens do social que revelam a existência de espaços de cultura e alteridade, produtos vitais do mundo concreto, do imaginário e da imaginação ${ }^{1}$.

A diversidade cultural presente nisto que chamo de textos culturais da infância é uma significativa expressão de como se constrói a alteridade, posto que outras imaginaçôes, outras subjetividades conduzem o olhar sobre a infância, a compreender-lhes os interditos. Nesses textos, o real representa-se como parte do imaginário daqueles que vivem sua infância num contexto social marcado pela alteridade e pelo poder. $\mathrm{O}$ imaginário diz respeito, portanto, à parte cativa de nossa imaginação. Cativa pelos valores dominantes, pelo poder das mídias, dos meios de comunicação e aprisionada num modelo de sujeito humano que se espera todos e cada um venham ser.

Para além dos elementos presentes na cena empírica do cotidiano, nessas imagens visuais e textuais, sempre busquei o inusitado que incita a transgressão criadora que envolve a imaginação. Esta permite dimensionar as marcas, os ritmos das práticas culturais, num processo ambíguo de afirmação e negação, de denúncia e consciência a que denomino Jogo de Imagens.

Nesse jogo, as imagens revelam a experiência cotidiana, unida aos valores do social cujos significados, numa forma de linguagem visual compartilhada, falam da vida em sociedade, do modo como os indivíduos são classificados e de como podem ou devem relacionar-se entre si, com a natureza e com o cosmo (Vidal, 1992, p. 284). Dois exemplos evidenciam como culturas diversas privilegiam conceitos e representaçóes, também diversas, presentes no cotidiano da vida ordinária.

Num primeiro caso - aqui ilustrado pela Figura 1 -, os conceitos e as representaçóes ligam-se:

- às relaçóes entre individuos e grupos em sociedade

$\mathrm{O}$ texto escrito e as imagens que o acompanham apontam qualidades diversas para negros e brancos, dizendo do comportamento esperado e sugerindo o que acontece nas relaçôes entre a criança negra e a criança branca: "o branco chinga (sic) o negro". O segundo texto reforça o próprio desenho, identificando a condição negra do autor, ao dizer: "o preto é mais escuro e não podemos (sic) chingar os outros” - (quem não pode? - nós, negros). O desenho dessa criança revela a

Muitas passagens do presente texto foram compiladas de outros textos e de falas de minha autoria, já publicados, mas que aqui têm por função aproximar a Antropologia do percurso e itinerário de Mário de Andrade e suas relações com o universo infantil, conforme solicitado para palestra em evento promovido pelo Instituto de Estudos Brasileiros (IEB) da USP em 20 I0. Trata-se, portanto, de releituras entre novos argumentos em torno da temática proposta. 
percepção de estar num grupo e fazer parte de uma dada realidade que se encontra dividida em segmentos com marcas sociais específicas, em relaçóes de poder diversas, conforme se faça parte de um ou de outro segmento.

Figura I - Desenho de criança negra

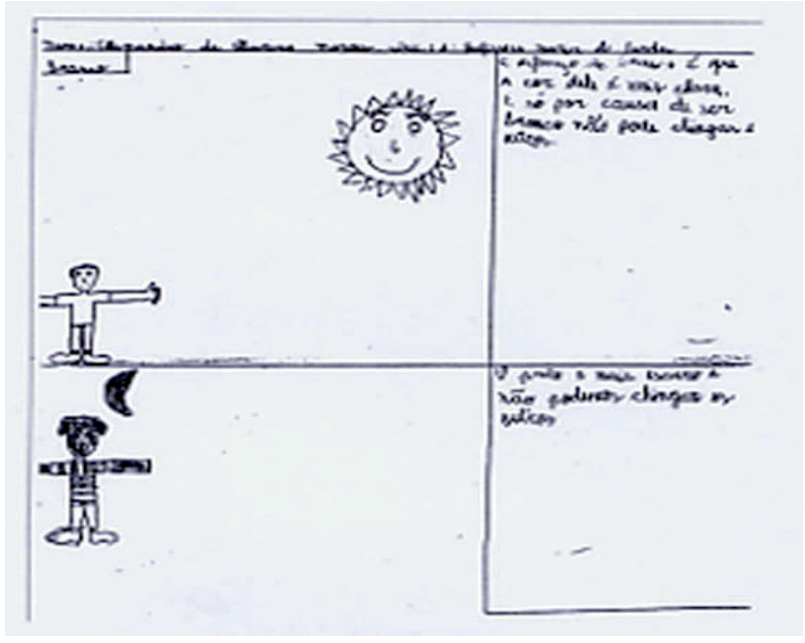

Fonte: Gusmão, 1999

Num segundo caso, a Figura 2 expóe os conceitos e as representaçóes:

- representam entidades sobrenaturais e conceitos cosmológicos mais amplos

Figura 2 - Desenho de criança indígena

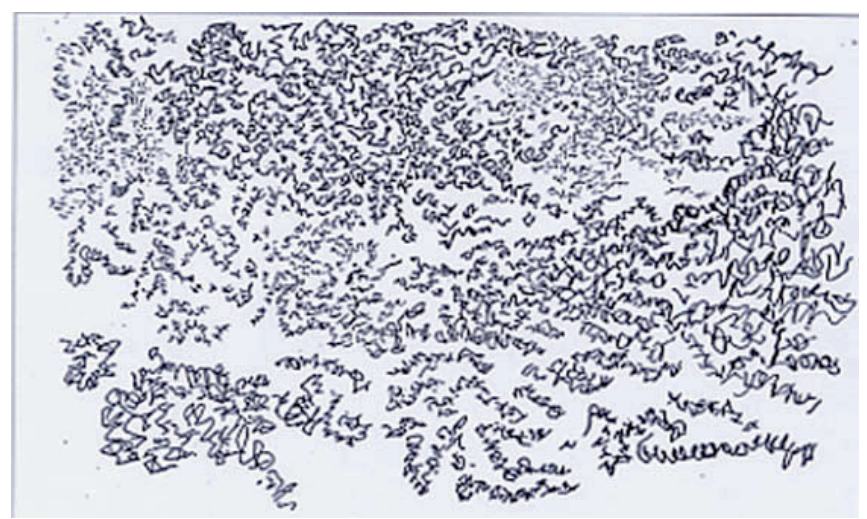

Fonte: Andujar, 1982 
O autor, uma criança Yanomami, afirma que desenhou a vida de seus dedos, a força vital emitida pelos seus dedos. O que diz é claro: trata-se da visáo de mundo Yanomami ${ }^{2}$ representada graficamente. O desenho fala, por si mesmo, da interioridade que habita o indivíduo e da coletividade de que ele faz parte e que transcende sua exterioridade. $\mathrm{O}$ desenho dessa criança indígena diz de sua condiçấo integral de $S E R$, enquanto membro de um grupo e de uma cultura singular.

Os dois exemplos são parte do caminho que escolhi para falar de algo que sabemos, mas que, com frequência, esquecemos ou negamos em nossos discursos acadêmicos e sociais: que as crianças, de qualquer grupo, sociedade ou cultura, sabem de si, sabem onde estáo, o que faz parte de suas vidas; conhecem seu mundo; e se confrontam com os princípios de pertença e identidade que lhes são atribuídos. Os exemplos acima evidenciam que

antes de qualquer coisa, os desenhos como imagens constituem a legitimaçáo e a memória que reflete as condiçôes sociais. Reflete, também, a consciência social que prevalece mesmo de modo indireto e que se expressa por meio de conteúdos manifestos ou latentes, cuja interpretação supóe o conhecimento exaustivo da realidade concreta. (Gusmão, 1993, p. 53)

As imagens expressam as relaçóes, as associaçóes e os sentimentos em relação ao vivido e permitem associar significados do que se é e do que se poderia ser na relação com o outro, um igual ou um diferente. Revelam, ainda, a partir da experiência concreta, a representação e a expectativa de que somos portadores diante da vida. Portanto, grafismos e desenhos são gritos silenciosos que, via imagens e representaçôes, ligam açôes concretas com experiência. E ainda, abstração, cognição, comunicação que estão referidas às múltiplas possibilidades de interação social e comunicativa. Isso quer dizer que a sociedade moderna e dominante, sociedade da escrita que caça a palavra de quem é menos, que não o deixa falar, não é - nem pode ser - absoluta em seus propósitos. Mostra que, tendo-lhe sido negado o direito a uma vida plena, ela, criança, encontra outras formas de expressar o que sente. Diz, assim, de outra forma, o que não pode dizer, pura e simplesmente pela fala. A reação dos sujeitos sociais, suas transgressóes, mesmo nas brechas do sistema, revela que a cultura nunca é inteiramente fechada e a criança sabe o que vive e comunica aquilo que sabe. É o adulto que não a ouve ou vê, deixando de aprender com ela, e, assim, não estabelece a comunicação e o trânsito entre vivências, saberes, aprendizagem e ensino.

2 O texto que acompanha a imagem explica que os Yanomamis acreditam que tudo no mundo, animal, vegetal ou mineral, consiste numa casca que contém a "energia da vida". O desenho é a "energia da vida que sai do homem" e flui pelos dedos dessa criança.

Pro-Posiçôes, Campinas, v. 23, n. 2 (68), p. 161-178, maio/ago. 2012 
Neste preâmbulo, cabe perguntar: o que esse pensar e refletir tem a ver com Mário de Andrade e com a Antropologia?

\section{Mário de Andrade e a Antropologia}

O olhar em torno de diferentes imagens, sejam elas de filmes, desenhos, fotografias ou outras quaisquer, permite uma viagem pela imaginação e a descoberta de múltiplas linguagens do social. Uma viagem que se debate entre contextos, situaçóes e fatos, mas que pressupóe a possibilidade alternativa daquilo que ela própria representa. Nesse sentido, as imagens náo dizem tudo, mas sempre dizem algo a respeito de alguma coisa. O que dizem e o como dizem operam nossas mentes culturais e colocam-nos como sujeitos de imaginário próprio, resultantes de uma dada cultura, de uma dada sociedade, de um grupo e lugar. Assim, estabelece-se um divisor de águas entre imaginário social, sempre cativo do mundo da ordem, e a imaginação, espaço de criação e liberdade. Nesse contexto, o desafio está em compreender a mente humana, conformada de forma aberta pela natureza, pela sociedade e pela cultura. Não há, portanto, um absoluto imaginário que opere a mente humana, posto que esta seja, sempre, produto de condiçóes históricas concretas e determinadas e, como tais, sempre relativas. Nesse sentido, o espaço da produção social, ainda não inteiramente cativo das convençôes e do campo de poder, torna-se um espaço potencial de descoberta e transformação. Aí, constitui-se a Antropologia via a descoberta de outras lógicas sociais e das muitas possibilidades de realização do viver humano. Um viver que se expressa de diferentes formas, em múltiplas práticas, em atos constitutivos de múltiplas imagens e linguagens.

Pode-se dizer que as práticas sociais de indivíduos que compartilham uma dada realidade conformam imagens cujas formas, por mais diversas que sejam, constituem linguagens que dizem do grupo, da sociedade e da cultura. Assim, o mundo real e a realidade de diferentes sujeitos são o centro do olhar antropológico que, muitas vezes, olha para o aparentemente banal e insignificante das práticas humanas, para descobrir que é aí onde o homem, a mulher, a criança, o indígena, o ser humano em geral, melhor se expressam. Assim, o que um grupo, uma sociedade, uma cultura dizem encontra seu limite e suas possibilidades no âmbito das relaçóes entre os homens, de maneira situada no tempo e no espaço.

Portanto, cabe reconhecer que o caminho do imaginário ocidental penetra no mais profundo dos cotidianos sociais de diferentes grupos e neles opera a percepção de mundo, percepção esta que nem sempre, ao contemplar o outro, o vê em sua dimensão e realidade. Assim, muitas vezes, vê-se o corpo dos sujeitos sociais, mas não sua alma. Com isso, o que se constrói faz parte de um conhecimento compartimentado que ora vê uma coisa e não vê outra; vê um cotidiano pleno de marcas e alegorias, mas o naturaliza e passa ao longe de poder compreender os fatos, 
compreender as múltiplas linguagens do social, inscritas nas dimensóes ocultas do cotidiano, num trânsito entre o real instituído e o real instituinte. Nesse trânsito opera a Antropologia, e atuou Mário de Andrade, em seu projeto e em sua busca pelo imaginário da infância, com suas danças e seus desenhos representativos da especificidade da criança como sujeito e de sua relação com o outro, o adulto, a cultura, a sociedade. Para Mário, as múltiplas linguagens do social, como desenhos infantis, contos, danças e cantos populares, tidos como folclore, teriam a condição de permitir apreender a realidade brasileira e compreendê-la em seus próprios termos, ou seja, dentro de uma concepçáo nacionalista, no desejo de pensar o Brasil e seu povo ${ }^{3}$.

Por outro lado, como intelectual polivalente, Mário pôe em prática seu projeto, não apenas por aquilo que se encontra no desdobrar de sua vida, de sua obra e de sua atuação em diferentes campos, como aponta Gobbi (2010). Ele o faz, também, porque, entre os anos de 1929 e $32^{4}$, torna-se um estudioso dos assuntos culturais brasileiros e busca conhecer a Antropologia brasileira que se pratica. Como diz Valentini (2011), a motivação principal do "namoro" com a Antropologia foi o projeto de uma arte inteiramente nacional para consolidar um ideário de nação brasileira, presente também nos modernistas da época. Nessa medida, torna-se, ele próprio, um "turista aprendiz a caminhar por diferentes paragens" (Gobbi, 2010, p. 71, nota 2, grifo da autora). Como aprendiz, não apenas irá transitar por lugares distantes da sociedade brasileira, coletando e sistematizando inúmeras manifestaçóes culturais, como também irá se aproximar do mundo acadêmico paulista em formação, particularmente na USP, e dos professores franceses que chegam com a missão francesa a São Paulo ${ }^{\bigotimes}$. Entre estes, Claude Lévi-Strauss, ainda preocupado com a Sociologia, mas que se fará antropólogo em solo brasileiro, e sua esposa, Dina Dreyfus Lévi-Strauss.

As intensas trocas, os fecundos diálogos e as experiências partilhadas entre o casal Lévi-Strauss e Mário de Andrade são, assim, constitutivos da Antropologia brasileira daquele momento. Pode-se afirmar que os interesses em comum no campo das artes e das ciências sociais em constituição no Brasil os conduzem, tal como demonstra o trabalho de Valentini (2011), a conformar um laboratório de Antropologia que será o embrião da Sociedade de Etnologia e Folclore, fundada no ano de 1937. Assim, "a possibilidade de reconstrução histórica da vida cultural, seja dos ameríndios, seja do povo brasileiro, atravessa as indagaçóes de Lévi-Strauss, Dina Dreyfus e Mário" (Valentini, 2011, p. 84) e transita deles para os modernistas, possibilitando, nessa experiência compartilhada, criar condições para excursões

\footnotetext{
3 A discussão sobre o nacionalismo de Mário de Andrade e dos modernistas está presente em várias obras, algumas das quais se encontram citadas no presente trabalho. $\bigcirc$ mestrado de Vianna (2002) é um exemplo.

4 Ver, a respeito, o trabalho de Telê Ancona Lopes (1972) referenciado ao final deste trabalho.
} 
pelo território nacional e para o fazer das "etnografias de domingos", em passeios pela cidade de Sáo Paulo, com a preocupaçáo de "retraçar as origens das culturas", como diz Valentini ( 2011, p. 85).

Em suas viagens em torno do que se denominou Missão de Pesquisas Folclóricas pelo norte e nordeste do País, segundo Telê Ancona Lopes (1972), é que Mário se faz "visitante que conta o que vê", na melhor tradiçâo dos textos etnográficos elaborados por antropólogos. Reúne, assim, uma imensidão de elementos folclóricos regionais, tais como contos, danças, mitos, músicas e outros tantos, constitutivos da chamada cultura popular. Busca nessas múltiplas linguagens compreender o povo brasileiro e dizer dele por seus próprios termos. No imenso acervo de fotos e imagens dos lugares por onde passa ao longo das viagens, reúne um significativo conjunto de desenhos infantis e também o faz em creches infantis que funda na cidade de São Paulo, quando assume o Departamento de Cultura e Recreação do Município de São Paulo. Do olhar que tudo registra, descreve e reflete emerge a concepção avançada para a época, da criança como sujeito social, produtor de cultura; e o mundo da infância será compreendido por ele como espaço de manifestação de uma ou mais culturas da infância e um dos espaços fundamentais para colocar em prática aquilo que Mário pensa em termos de outra nação brasileira ${ }^{\square}$

O ideário de outra nação brasileira e de justiça social que o leva a criar as creches para as mães operárias na cidade de São Paulo é parte do mesmo motivo que o leva a percorrer grande parte do território brasileiro. Nesse movimento copila canções folclóricas e costumes das gentes comuns, num abraço fraterno com a Antropologia, que começa a ensaiar seus passos no Brasil.

O cotidiano do brasileiro comum que desafiou Mário de Andrade é, assim, o mesmo que desafiou Lévi-Strauss e sua esposa Dina e que desafia a Antropologia em seu percurso, no seu fazer diante da imensa diversidade humana. É por esse parâmetro que se podem apontar alguns aspectos a respeito da criança, da infância e sua relação com o mundo adulto, tanto nas preocupaçóes de Mário de Andrade como na Antropologia. Contudo, qual o olhar desta ciência sobre a criança e a infância? Como esse olhar dialoga com os caminhos e as iniciativas que marcaram a atuaçáo e a obra de Mário de Andrade?

\section{Territórios de aprendizagem: questões da alteridade}

Tratamos, aqui, das chamadas relaçóes perigosas, quer a relação entre saberes diversos - o saber científico e o saber popular -, quer as relaçóes que ensejam a apropriaçáo dos fatos sociais, cuja reinterpretação depende tâo somente da imaginação, esta, sim, ponto de força, de transgressão criativa e libertadora, na qual o homem não apenas imita, reproduz, mas inventa e cria. Este é o território das sociabialidades humanas, espaço fértil da cultura como produção e produto, como 
equilíbrio e conflito, como trama e textura do social. É o território, por excelência, da criança e seu mundo de infância. Nele, a cultura se faz enquanto acontecimento, rotina e ruptura, parte do revestimento mais de superfície da sociedade, mas também seu cerne, a parte profunda que a constitui enquanto emoçóes, hábitos, sentimentos, representaçóes e conflitos. Para o sujeito social, a cultura é e representa a experiência vital de seu tempo e de seu espaço em termos de si mesmo e do outro. A alteridade constitutiva da própria condição de humanidade é, assim, fundamental para a vida social, para a vida em sociedade.

Contudo, em sociedades como a nossa, a alteridade da infância está em relação direta com o mundo adulto; e, em muitos momentos, o mundo de uma e o de outro, ainda que se toquem e se cruzem, permanecem separados, não permitindo compreender a natureza política que os constitui como sujeitos em relação. Essa invisibilidade ou negação da infância será denunciada por Mário em termos do adultocentrismo das relaçóes com a criança, e a intensa busca por mapear a realidade do mundo infantil o levará a afirmar como sujeito de cultura, a criança e o seu mundo, um mundo pleno de culturas singulares.

Cohn (2005, p. 8) sintetiza bem o olhar antropológico sobre a questão, ao afirmar que é preciso "entender a criança e seu mundo a partir de seu próprio ponto de vista" e que é por isso que uma Antropologia da Criança se faz importante nos dias de hoje. Afirma, ainda, que a Antropologia reconhece a "criança como sujeito social ativo e atuante, produtor mais que receptor de cultura" (Cohn, 2005, p. 42). Nesse sentido, Mário foi precursor dessa Antropologia da criança em construção no Brasil de agora, como bem mostra Gobbi (2010, p. 74), ao afirmar:

Mário de Andrade, no período histórico em que escreve [sobre criança e infância] encontra-se na intersecção entre concepçóes que apontam a criança vista e dita somente por adultos, que, ao traduzirem seus comportamentos, revelam a percepção da criança como uma não falante, logo, não desenhista, não expressiva, e outros modos de compreender a infância que procuram representá-la em seu universo, ouvindo suas vozes para apreenderem suas formas de ver o mundo.

Para além do adultocentrismo hoje criticado na apreensão do mundo da infância e do reconhecimento das múltiplas formas de ser criança, por vezes, ainda acontece de as crianças serem vistas, pelos adultos e também pelos educadores, como iguais, homogêneas, tendo os mesmos interesses e necessidades, típicas desta ou daquela idade. Como tal, deve aprender este ou aquele conteúdo, independentemente de compreender sua razão e seu funcionamento. São, assim, somente crianças, crianças de pouca idade. Mas o que é a idade, senão aquilo que levamos conosco? Que herdamos ao nascer e que vamos criando enquanto vivemos a partir do que o mundo nos diz e tal como se nos apresenta? 
Diante dessa questấo, deve-se ter em conta que o adulto, ao não levar em conta - até por náo perceber - a trama de relaçóes existentes entre sujeitos diversos em tempos e espaços os mais diferentes, bem como os múltiplos sentidos construídos na vida que temos, acaba por considerar a criança apenas enquanto ser de cognição e, mesmo assim, de forma equivocada, posto que a vê apenas com maior ou menor capacidade de aprender conteúdos e comportamentos; com maior ou menor disciplina na casa, na rua, na escola. O que não é levado em conta é que a criança é um sujeito sociocultural - sujeito de experiência e de cultura próprias ou, como dizia Mário de Andrade, com capacidade de ler o mundo e criar suas culturas (Gobbi, 2010). Como, entáo, permanecer no saber instituído, se a criança também é capaz de produzir o mundo em que está e em que vive para além do que lhe é dado? Ao fazer tal questionamento, a Antropologia e o antropólogo, segundo Cohn (2005, p. 50), devem dar conta de que "não há imagem produzida sobre a criança e a infância, ou pela criança, que não seja, de algum modo, produto de um contexto sociocultural e histórico específico".

Em sociedades como a nossa, sociedade de classes, no caminho pelo qual a criança adentra o mundo adulto - o mundo a sua volta e no qual se acredita seja o adulto detentor de um saber -, propóe-se a ela ser nele iniciada. Nesse processo, a criança, segundo o adulto, "deve ser preparada para repetir o que [os adultos] fazem”, num processo de ensino, mas não de aprendizagem (Iturra, 1994, p. 31). O ensino é, assim, "repetir criando uma subordinação; a aprendizagem é descobrir, criando uma relação de comunicação" (Iturra, 1994, p. 31, grifo meu), na qual criança e adultos interagem. O próprio Iturra, em entrevista, exemplifica com sua experiência em campo tal situação. Diz ele (1994, s.p.):

as crianças de uma aldeia onde passei muitos anos de estudo - Vila Ruiva, na Beira Alta - não sabiam quem era São João. Quando perguntaram aos pais, eles apenas lhes souberam dizer que "foi um santo que viveu há muito tempo, para aí há cem anos...”. Eu expliquei-lhes a verdade através do método comparativo: fiz com as crianças cálculos sobre a idade do pai, do avô, do bisavô que já estava morto, e elas perceberam que cem anos não era tanto tempo como parecia. Só depois lhes disse que São João tinha baptizado Cristo. Este método abriu os seus entendimentos, e hoje aqueles miúdos estáo todos no secundário ou na universidade. Há uma aprendizagem da ciência na vida pragmática.

Para a criança, portanto, o que está em jogo é a possibilidade de experienciar o mundo, descobri-lo em seus elementos, o que ela faz por meio da comparação entre o que sabe, vê, ouve e observa, entre iguais, as outras crianças; e com este outro, diferente dela, o adulto. Este é, porém, um sujeito contraditório. Como 
dizem Sarmento e Pinto (1997, p. 13), para o adulto e para o mundo que ele representa, as crianças são importantes e sem importância; espera-se delas que se comportem como crianças, mas são criticadas nas suas infantilidades; é suposto que brinquem absortas quando se lhes diz para brincar, mas náo se compreende porque não pensam em parar de brincar quando se lhes diz para parar; espera-se que sejam dependentes quando os adultos preferem a dependência, mas deseja-se que tenham um comportamento autônomo; deseja-se que pensem por si próprias, mas são criticadas pelas suas "soluçôes" originais para os problemas.

Assim, na contemporaneidade, a criança e a infância tornaram-se um paradoxo: fazem parte de uma complexidade social e de uma heterogeneidade fruto das condiçóes de vida, e sobre elas incidem imagens, concepçóes e atitudes igualmente contraditórias. A criança percebe isso e sabe disso, e acaba por não se ver ou se reconhecer naquilo que os adultos colocam como razão de ser de seu mundo. Por essa razáo, a criança foge ao adulto para construir, com outras crianças, sua compreensão das coisas. Como ela o faz? Comparando o que vê, ouve e experimenta na relação com todos aqueles que estão em seu mundo. Comparar se faz, então, como parte do aparato próprio do pensamento humano diante das informaçóes e dos fatos dispostos na realidade social por meio de seus pares, outras crianças, e pela relação com o adulto. Aqui sobrevém a importância da sociabilidade que se expressa em meio a brincadeiras, jogos, cantos e danças, entre muitas outras formas de expressão no mundo infantil.

Não por acaso será esse universo um dos espaços de maior observação, registro e referência na obra e na atuação de Mário de Andrade, dela resultando um imenso acervo de cantigas, desenhos, contos, etc. atribuídos ao mundo da infância. Assim, segundo Gobbi (2010, p.74), "a infância é retirada do silêncio que tanto a ocultou na história, e que, consequentemente, ocultava suas criaçóes, conquistando um espaço e status diferenciado". Nesta nova compreensão e apreensão do mundo da infância, não se nega, senão que reconhece a presença do adulto, porém, não mais como referência absoluta. Como diz Cohn (2005, p. 35), "as crianças não são apenas produzidas pelas culturas, mas são produtoras de cultura” e, mais que isso, "as crianças têm autonomia cultural em relação ao adulto".

O que a análise da farta coleção pessoal de desenhos de crianças e de jovens coletados e organizados por Mário de Andrade proporciona à reflexáo antropológica é a descoberta do mundo da infância como parte de outras lógicas estruturadas pelo ato de comparar. Ato no qual a criança estabelece um conhecimento de si mesma, do outro, do mundo no qual está. O processo, em si, consiste numa aprendizagem. Cabe, porém, compreender que a criança e o adulto têm em comum esse procedimento, que é parte do pensamento humano. Comparamo-nos uns aos outros para formar a imagem que temos do que somos, do que queremos e do que náo queremos para compor nossa compreensão das coisas. Quando o fazemos a partir 
de nossa trajetória, da nossa história de vida, refletindo sobre ela, conseguimos melhorar qualitativamente o próprio conhecimento e o entendimento das coisas, tornamo-nos pessoas reflexivas e investigativas e, como tais, transgressoras e criativas. Para Iturra (1992), a transgressão é a marca fundamental da infância. É a forma e a maneira pela qual a criança comprova se o seu julgamento das coisas é razoável ou não diante do que diz e manda o adulto, porém não claro ao seu entendimento infantil. Então rebela-se, zanga-se e cria um mundo onde espelha o que recebe e o redimensiona com seus iguais. Náo se trata de desobediência, mas é, como diz Iturra (1992, p. 496), "a procura do entendimento do que lhe é mandado", posto que vê e percebe o mundo adulto como cheio de regras e de normas, as quais nem sempre correspondem ao comportamento do próprio adulto. Trata-se de um modo de ver, ouvir e perceber o mundo a sua volta. Pode-se dizer, para investigá-lo e colocá-lo a sua altura e medida.

O processo de investigar exige "se saber quem se é, quem se quer ser e como e quem são os outros" (Vieira, 1999, p. 140) com os quais vivemos e com os quais construímos e experimentamos o mundo. É nesse sentido que a criança pergunta muito e também age, muitas vezes, de modo que o próprio adulto não compreende. Essa é a razão sobre a qual importa refletir, em relação ao adulto que educa e ao papel que desempenha como mediador entre o saber produzido pela sociedade e por seus grupos - um saber legitimado - e esse outro saber que emerge da experimentação e da observação do mundo a nossa volta enquanto vamos vivendo. Pode-se dizer que o olhar de Mário sobre as produçóes infantis vem marcado por ambas as dimensóes - o saber adulto e legitimado pela ordem social e aquele que resulta da própria vivência da criança com os pares e também com o próprio adulto.

Nesse contexto, compreende-se que a criança queira aprender, não só porque será aprovada e aceita pelo adulto, coisa que não nega e deseja, mas porque, por esse caminho, começa a entender tudo que a envolve. O acesso ao saber é, assim, o caminho pelo qual crianças e adultos se tornam capazes de entender o mundo em que vivem, compreendendo suas contradiçóes e seus limites.

\section{A Antropologia, a comparação e a escola}

A admissão da heterogeneidade do mundo social nos coloca diante das diferenças - o que eu sou, o que o outro é - e, aqui, tudo se complica. "A imagem do outro é uma contradiçáo" e, nesse sentido, diz Larrosa (1998, p. 67), as crianças se tornam "seres estranhos dos quais nada se sabe", são "seres selvagens que não entendem nossa língua" e como tais devem ser "educados", ou melhor, "ensinados". A questão é: a escola ensina ou educa? Ou deve ensinar e educar a um só tempo?

Para a criança, a aprovação e o respeito social resultam do saber oficial, sistemático e abstrato, com o qual ela ganha aprovação dos adultos. É pelo saber formal e 
abstrato, e só por ele, que aceita o que se passa em torno de si mesma, ainda que náo o compreenda. Essa relaçáo, baseada no ensinar e no memorizar, próprios do mundo adulto e da escola, é, então, uma relação de poder que cinde a experiência que a criança traz consigo, como parte de sua história e do grupo ao qual pertence, negando outro saber, produzido por relaçóes marcadas pelo experimento e pela experiência; negando a afetividade entre sujeitos no processo educativo que vai além da escola.

É nesse sentido que a escola, com seu saber instituído, tal como o ser adulto, nega a criança como sujeito da história, produto e produtor de cultura; nega sua especificidade, fazendo tábula rasa de suas experiências e de suas narrativas, não permitindo que se ponha em movimento a possibilidade da comparação e, por meio dela, a descoberta e a aprendizagem. A escola se esquece de que a criança não é uma folha em branco, sobre a qual a sociedade imprime seu texto, já que, "folha e texto são gerados juntos" (Rodrigues, 1992, p. 122). Isso significa afirmar que a criança traz consigo sua mente cultural, que náo é considerada no interior da escola. Deixa, assim, de se fazer matéria-prima do processo educativo escolarizado, de modo a permitir, ao adulto que ensina, educar através da ordenação de questionamentos e informaçóes que permitam a aproximaçáo organizada entre saberes - vale dizer, pela comparação - e, com isso, deixa também de obter o prazer da descoberta e a efetiva aprendizagem, tal como acontece fora da escola - na rua, no quintal, em casa, nos espaços de lazer partilhado.

Nesse sentido, a Antropologia e seu método, a comparação, propóem colocar aprendizagem e ensino em relação, na escola e fora dela, no interior dos mais diversos processos educativos a que o ser humano está submetido desde que nasce. Contudo, a Antropologia aponta, também, para os limites da escola moderna, estruturada táo somente como ensino; e propóe que se recupere a importância da transmissão cultural entre crianças, o papel das brincadeiras aprendidas entre pares, seja na escola, no pátio, fora das salas de aula ou ainda em cançóes e danças, que, como diz Cohn (2005), buscam dimensionar a simbologia que as embasam e que conformam diferentes modalidades de produção cultural. Se isso importa à Antropologia da Infância, também foi importante para Mário de Andrade em suas pesquisas com crianças nas creches infantis, como bem apontam os trabalhos de Faria (1999) e Gobbi (2010), entre outros autores. Para a Antropologia, "espaços especializados de aprendizagem podem ser encontrados ao redor do mundo, transmitindo conhecimentos os mais diversos, em modalidades as mais diversas" (Cohn, 2005, p. 37); e a comparação, como método, ou seja, como procedimento sistemático, pode fornecer instrumentos necessários à organização do pensar sobre o real, de modo a não subtrair a experiência e a subjetividade do olhar da criança, mas a incorporá-lo de forma objetiva na construção de sua percepção de mundo, que cabe ao adulto intermediar, como ensino e como aprendizagem. 
Conto-lhes um pequeno episódio que vivi em uma creche portuguesa. Duas crianças bem pequenas colhem matos do jardim mal cuidado como se fossem flores, fazendo com eles pequenos buquês. Eu, em pé, as observo. Elas também me olham, cochicham e riem. Aproximam-se e me oferecem o buquê de flores. Abaixo-me e o recebo. Elas, então, riem, brincam e me afagam o rosto e os cabelos. Perguntam-me quem sou e onde moro. Digo-lhes meu nome, que não sou dali e que moro bem longe, do outro lado do mar. Alguns segundos depois, após perceptível reflexão, diz-me uma delas: "Eu sei. Outro dia eu fui lá, bati na porta de sua casa, mas você não estava e eu vim embora." Resolvida a questão: do outro que sou, uma estranha, passo agora a integrar seu mundo, torno-me familiar. Sou um outro e um mesmo, condição insuspeita da totalidade do SER, sem adjetivos ou divisões.

A intolerância que divide é um componente do mundo adulto, do mundo do poder, do mundo moderno e capitalista, marcado por suas divisóes de classe, idade, etnia e outras. Assim, na nossa sociedade,

toda criança que nasce entra já no mundo das classificações feitas e das hierarquias estabelecidas. O seu papel, goste ou não, saiba ou não, é o de reproduzir, da forma mais perfeita possível, o mundo que os adultos the organizam (Iturra, 1992, p. 493).

No entanto, o exemplo citado e toda a discussão de Mário sobre a infância podem ser sintetizados no que diz Larrosa (1998, p.71) sobre a criança:

a experiência da criança como outro: o encontro com uma verdade que não aceita a medida de nosso saber, como uma demanda de iniciativa que não aceita a medida de nosso poder e com uma exigência de hospitalidade que não aceita a medida de nossa casa.

Por essa razão, não é verdade que a criança tenha medo do adulto, é este que tem medo da criança e necessita, portanto, colocá-la sob controle por meio de muitos mecanismos, entre eles, a educação que homogeneíza e nega as diferenças, uma educaçáo que subordina e impede outras descobertas, possíveis pelo universo não cativo da imaginação. Compreender o outro, portanto, seja ele uma criança ou não, não consiste só em falar sua língua para ouvir e perceber, mas exige "também conhecer sua cultura, ou melhor, sua mente cultural, o seu contexto, a sua mentalidade, porque significados há que restam subjacentes ao discurso verbal, tâo ou mais importantes para a decodificação da mensagem a entender" (Vieira, 1999, p. 133).

Segundo Vieira, compreender a criança é entrar no seu contexto, no interior de sua mente cultural, participar desse crescimento e crescer junto. Partilhar é a 
essência de uma educação intercultural e emancipadora; nela não se nega o outro, fazendo-o à nossa imagem e semelhança, mas assume-se o que somos de modo a nos fazermos sujeitos significantes uns com os outros, uns através dos outros, por meio de nossos símbolos - o mundo da cultura; de nossos poderes - o mundo da política; e de nossas instituiçóes sociais, entre as quais se insere o espaço educacional com as práticas que lhe são próprias, ou seja, as creches, as escolas, as famílias, etc.

A pergunta que nos interpela como educadores é, então, como efetivar uma prática que dê conta de tudo isso? Como saber escutar a criança e receber dela a verdade daquilo que nos diz? O que fazer diante de crianças inconformistas e transgressoras? $\mathrm{O}$ que fazer diante dos processos educativos, pautados em valores gerais e abstratos, que náo reconhecem a criança como produtora de cultura? Como responder a isso tudo, se na sociedade moderna a vida adultocentrada reconhece a condição de produtivos apenas aos jovens e aos adultos, relegando a criança à condição de não ser ou de alguém que ainda não é?

Aqui, antropologicamente, a produção de Mário de Andrade ganha intenso sentido e significado, pois permite compreender a criança como sujeito que desafia a compreensão de si mesma perante a ordem instituída, uma vez que o ciclo de vida é um elemento importante na construção da percepção de si e do outro, tanto para o indivíduo como para o coletivo. Nessa medida, criança e infância nem sempre correspondem ao que delas se pensa ou se espera. Seus atos, comportamentos e atitudes, muitas vezes incompreensíveis ou desafiadores do espaço do adulto e de suas concepções, são um desafio paradoxal e presente. Constituem, antes de tudo, um enigma que coloca em risco a reprodução do mundo moderno e a segurança de sua continuidade.

Diante desse desafio, o adulto toma em suas mãos a infância como matériaprima de realizaçáo das expectativas postas pelo sistema como futuro. Deixa de reconhecer as especificidades de que a infância é portadora no aqui e agora de suas vidas e, num ato de poder, busca fazer da criança um igual a si mesmo, alguém de quem se espera possa, não apenas repeti-lo, mas ir além e, assim, realizar o que ele, adulto, não conseguiu em sua própria trajetória diante das exigências de seu mundo. Como diz Larrosa (1998, p. 78), "as crianças são assim sacrificadas a esse ídolo ávido de sangue infantil cujos nomes são Progresso, Desenvolvimento, Futuro ou Competitividade".

O desafio do educador é encher-se de coragem, tomar as mãos da criança e seguir com ela ${ }^{5}$. Isso exige abandonar o imaginário cativo, próprio do mundo da ordem, e permitir-se dar asas à imaginação, território constitutivo da liberdade e das possibilidades de SER, de modo total e sem amarras. Um educador sem a imaginação daqueles que educa, em confronto com a sua própria imaginação, não

5 Sobre esta temática, ver Gusmão,2003. 
compreende a natureza do que observa, do que vê e experimenta na relação com esse outro sujeito que com ele partilha a vida.

Cabe ao educador o exercício constante de compreender-se a si mesmo, resgatando sua infância na infância do outro; resgatando as experiências vividas por ele próprio e pela criança; e resgatando, também, os adultos significativos que mediaram seus caminhos em busca de outros horizontes. Buscando compreender a razão de suas práticas e também seus limites; questionando o que acredita ser correto e abrindo seu espírito a outras narrativas, em particular, àquelas contadas pelo mundo da infância. Mário de Andrade, intelectual, homem público e educador, foi sensível ao mundo da infância, soube ouvir e captar-lhe as vozes, como afirmam Faria (1999) e Gobbi (2010), de modo a pôr em prática o que diz Nunes:

se deve dar atenção ao que a criança tem a dizer sobre o que está vivendo e aos vários modos de como ela expressa a compreensão de tudo isso. A criança vive e se manifesta dentro de limites e até amplitudes que lhe são próprios, muito embora existam zonas de intercâmbio com o mundo adulto. (Nunes, 1997, p. 4)

Por tudo isso, pode-se afirmar que

a criança não é uma versão reduzida do adulto nem este uma reprodução ampliada da criança. Não podemos deixar que a nossa habitual perspectiva "adultocêntrica" nos limite. Precisamos deixar de olhar as crianças como "adultos em potencial”, como alguém que ainda virá a ser. (Nunes, 1997, p. 4).

Não se deve, tampouco, fazer o "culto à criança" e correr o risco de um utopismo na busca de um ser humano diferente. É preciso olhar a criança como outro e como um mesmo, preservando a realidade daquilo que é a infância e seu mundo na relação com o mundo adulto, de modo real e concreto. A reflexão permanente sobre o outro exige, assim, pensá-lo como algo que nos inquieta e nos surpreende, mas é preciso deixar-se surpreender e querer ser surpreendido. Nessa medida, a criança e a infância que lhe é própria são também o enigma que nos desafia, desafia nosso conhecimento e nos coloca diante da circunstância de ter que admitir que não sabemos tudo, não detemos todo o conhecimento disponível sobre a realidade e as coisas.

Devemos, portanto, relativizar nossas convenções, crenças e valores; desnaturalizar a infância e, para além de seu escopo biológico e psicológico, compreendê-la enquanto uma construção da vida em sociedade. Razão que moveu Mário em suas pesquisas sobre o mundo infantil e que move a Antropologia diante desse mesmo universo. Contudo, importa termos clareza de que esta sociedade, nossa sociedade, 
do passado e do presente, não é uma sociedade qualquer. Falamos de sociedades modernas que, segundo Giddens (1995), são "sociedades cerradas", sociedades da negação, que discriminam e separam por estereótipos diferentes sujeitos sociais, entre estes, a criança. É preciso ver que isso constitui uma ideologia que precisa ser desvendada e implodida, para apreender a realidade social em nova dimensão. Vale, portanto, relembrar o poeta Fernando Pessoa e seu heterônimo Alberto Caieiro e refletir com ele.

\author{
POEMAS INCONJUNTOS \\ A criança que pensa em fadas e acredita em fadas \\ Age como um deus doente, mas como um Deus \\ Porque embora afirme que existe o que não existe \\ Sabe como é que as coisas existem, que é existindo \\ Sabe que existir existe e não se explica \\ Sabe que não há razão nenhuma para nada existir \\ Sabe que ser é estar em um ponto \\ Só não sabe que o pensamento não é um ponto qualquer.
}

(Alberto Caieiro, 1917)

Para um concluir, inconcluso...

A ambiguidade do concluir, inconcluso é aqui um recurso para dizer das ambivalências e ambiguidades que percorrem o fazer científico; neste caso, a Antropologia e o saber popular - visto em Mário de Andrade como folclore -, principalmente quando postos a dialogar. Presentes na Antropologia como ciência; na vida e na obra de Mário de Andrade; e em tudo aquilo que, de alguma forma, constituiu seu percurso de homem público e intelectual, tal diálogo faz dele um autodidata em folclore e Antropologia, como diz Maria Laura Viveiros de Castro Cavalcanti (2004). Segundo a autora, Mário utilizou a Antropologia contemporânea nos estudos do folclore, e pode-se dizer que seu interesse pelo folclore e pelos elementos étnico-culturais está bem retratado em Macunaíma: o herói sem nenhum caráter (1988).

Nessa magnífica obra, Mário fala, pelo personagem, de um país nascente, por se fazer. Fala de outra infância, a da nação brasileira. Macunaíma é o personagem que diz do povo brasileiro e de sua cultura, tal como dizem os contos, a arte, o folclore, as músicas e os desenhos das múltiplas infâncias possíveis, num mundo feito por crianças e adultos; por jogos de interesse e de poder; pela complementariedade e contradição de imaginários cativos e imaginaçôes possíveis. Macunaíma ou as infâncias das creches paulistas ou o contexto do interior do nordeste evidenciam um campo de tensão e de vida, de realidade e experiências, no qual se debatem, 
se confrontam e se contradizem os adultos e as crianças, a infância e a adultez, a sociedade brasileira constituída e um Brasil em construçáo. Permanecem em debate o saber instituído e legitimado como conhecimento e ideologia e o saber em movimento e em construção diária, no fazer e ser dos sujeitos sociais em relação, entre eles a criança e sua infância.

É assim que, concordando com o poema do alter ego de Pessoa, Alberto Caieiro, pode-se afirmar que o pensamento, como a vida que lhe dá consistência, não é um ponto qualquer; e sua natureza, sua razáo e seu funcionamento cabem ao educador, ao adulto mediar de modo crítico e reflexivo nas relaçóes que tem com o mundo da infância, com a criança, no próprio mundo e naquilo que ela sonha como nova realidade. Deslocam-se, portanto, o olhar e sua centralidade, postos no mundo adulto e constituído, para instaurar a reflexibilidade e a comparação, tão caras à Antropologia. E tornam possível a descoberta da alteridade e, com ela, a compreensão do que cada um tem a dizer sobre si mesmo - crianças e adultos - e, também, do mundo no qual estão e vivem, porém, de modo contextualizado e historicamente dado. Isso exige uma abertura para pensar quem somos e o que náo somos, reconhecer o mundo do outro no nosso mundo, a vida do outro como parte de nossa vida e estabelecer pontes, abrir portas para que o trânsito no espaço comum seja solidário e democrático. Para que seja possível outra sociedade, mais plural e mais justa.

\section{Referências bibliográficas}

ANDRADE, M. Macunaíma: o herói sem nenhum caráter. Ediçáo crítica. Coordenaçáo de Telê Porto Ancona Lopes. São Paulo: UNESCO, 1988. (Coleção Arquivos, v. 6)

ANDUJAR, C. Desenhos Yanomami. Arte em São Paulo, n. 5, São Paulo, mar. 1982.

CAVALCANTI, L. V. de C. Cultura popular e sensibilidade romântica: as danças dramáticas de Mário de Andrade. Revista Brasileira de Ciências Sociais (RBCS), São Paulo, v. 19, n. 54, p. 57-78, fev. 2004.

COHN, C. Antropologia da criança. Rio de Janeiro: Jorge Zahar, 2005.

GIDDENS, A. Sociologia. Madri: Alianza, 1995.

GOBBI, M. Conhecer infâncias brasileiras: meninos e meninas em contos de Mário de Andrade. Múltiplas Leituras, v. 3, n. 1-2, p. 70-85, jan./jun. 2010.

GOULART, A. L. F. A contribuição dos parques infantis de Mário de Andrade para a educação infantil. Educação e Sociedade, ano 20, n. 69, p. 60-91, 1999.

GUSMÃO, N. M. M. Socialização e recalque: a criança negra no rural. In: GUSMÃO, N. M. M. et al. (Org.). Educação e diferenciação cultural. Índios e negros. Cadernos Cedes, n. 32, p. 49-84, 1993. 
GUSMÃO, N. M. M. Linguagem, cultura e alteridade: imagens do outro. Cadernos de Pesquisa, São Paulo: Fundação Carlos Chagas; Campinas: Editores Associados, n. 107, p. 41-78, 1999. Ediçáo Especial.

GUSMÃO, N. M. M. Antropologia, processo educativo e oralidade: um ensaio reflexivo. Pro-Posiçôes, v. 14, n.1 (40), p. 197-213, jan./abr. 2003.

ITURRA, R. O processo educativo: ensino ou aprendizagem? Educação, Sociedade e Culturas, n. 1, p. 20-50, [s.d].

ITURRA, R. O jogo e a experimentação pessoal na infância: uma hipótese exploratória. Revista Portuguesa de Pedagogia, Lisboa, v. 26, n. 3, 1992.

ITURRA, R. O pior inimigo da Antropologia é o antropólogo. Entrevista concedida a Maria José Margarido para A Página, Arquivo Vivo n. 1, Ano 0, 1994. Disponível em: $<\mathrm{http}: / w w w . a p a g i n a . p t>$. Acesso em: 10 set. 2010.

ITURRA, R. O imaginário das crianças: os silêncios da cultura oral. Lisboa: Fim de Século, 1997.

LARROSA, J.; LARA, N. P. (Org.). Imagens do outro. Petrópolis, RJ: Vozes, 1998.

LOPES, T. P. A. Mário de Andrade: ramais e caminhos. São Paulo: Duas Cidades, 1972.

NUNES, A. M. Educação indigena: diversidade e cidadania. In: REUNIÃO ANUAL DA ASSOCIAÇÃO NACIONAL DE PÓS-GRADUAÇÃO E PESQUISA EM CIÊNCIAS SOCIAIS - Anpocs, 21., outubro de 1997, Caxambu. (mimeo)

SARMENTO, M. J.; PINTO, M. As crianças e a infância: definindo conceitos delimitando o campo. In: PINTO, M.; SARMENTO, M. J. (Org.). As crianças - contextos e identidades. Braga, Portugal: Centro de Estudos da Criança, 1997.

RODRIGUES, J. C. A infância e o poder. In: RODRIGUES, J. C. Ensaios em Antropologia do poder. Rio de Janeiro: Terra Nova, 1992.

VALENTINI, L. Diálogos entre Dina Dreyfus, Claude Lévi-Strauss e Mário de Andrade: algumas perspectivas sobre etnografia no entreguerras (1935-1938). Dissertação (Mestrado) - Programa de Pós-Graduação em Antropologia, USP, São Paulo 2011. Disponível em: $<$ http://usp-br.academia,edu/LuisaValentini/Papers/238734/Dialogos_Entre_Dina_ Dreyfus_ClaudeLeviStrauss_E_Mario_De_Andrade_Algumas_Perspectivas_sobre_a_ Etnologia_No_Entreguerras_1935-1938 . Acesso em: 15 jul. 2011.

VIDAL, L.; SILVA, A. L. Antropologia estética: enfoques teóricos e contribuições metodológicas. In: VIDAL, L. (Org.). Grafismo indígena. São Paulo: Studio Nobel; Fapesp; Edusp, 1992.

VIEIRA, R. Da multiculturalidade à educação intercultural: a Antropologia da educaçáo na formaçáo dos professores. Educação, Sociedade e Culturas, Porto, n. 12, 1999.

Recebido em 07 de abril de 2011 e aprovado em 22 de julho de 2011. 